\title{
IMPLEMENTATION OF ISO 9001:2015 AND ISO 14001:2015 IN COAL AND HEAVY METAL MINING SECTOR: STUDY CASE ON DEVELOPED AND DEVELOPING COUNTRY
}

\author{
Gilbert Givano'), Hiqmatus Sholichah $^{2)}$, Filson M. Sidjabat ${ }^{3)}$ \\ 1)2)3) Environmental Engineering, President University \\ Email : sholichahhiqmatus@gmail.com
}

\begin{abstract}
Many industries are currently racing in the world to achieve ISO certification. ISO gives world-class products and services to all businesses and organizations around the world. The 2 main standards that will be discussed are ISO 9001:2015 about Quality Management and ISO 14001:2015 about Environmental Management. Different companies may have different strategies in implementing these standards. Analysis of strategic comparison between developed country and developing country will be done, and also giving information for other standard ISO that is related to mining company. It is found out that the different kind of strategies in implementing ISO is the result of different needs of the company. Knowing this shows how coal and heavy metal mining industries are aware of the importance of these standards.
\end{abstract}

Keywords: ISO 9001:2015, ISO 14001:2015, Mining Industry, Strategy.

\begin{abstract}
Abstrak
Banyak industri saat ini berlomba di dunia untuk mencapai sertifikasi ISO. ISO memberikan produk dan layanan kelas dunia untuk semua bisnis dan organisasi di seluruh dunia. 2 standar utama yang akan dibahas adalah ISO 9001: 2015 tentang Manajemen Mutu dan ISO 14001: 2015 tentang Manajemen Lingkungan. Perusahaan yang berbeda mungkin memiliki strategi yang berbeda dalam menerapkan standar ini. Analisis perbandingan strategis antara negara maju dan negara berkembang akan dilakukan, dan juga memberikan informasi untuk standar ISO lainnya yang terkait dengan perusahaan pertambangan. Ditemukan bahwa berbagai jenis strategi dalam menerapkan ISO adalah hasil dari berbagai kebutuhan perusahaan. Dan mengetahui bahwa ini menunjukkan bagaimana industri pertambangan batubara dan logam berat menyadari pentingnya standar ini.
\end{abstract}

Kata Kunci: Industri Pertambangan, ISO 9001:2015, ISO 14001:2015, Strategi.

\section{INTRODUCTION}

In the world, nowadays, many industries race to achieve the ISO certification. ISO stands for 'International Organization for Standardization'. These standards give a world-class products and services to all businesses and organizations around the world. ISO has already published 22528 International Standards and related documents, covering almost every industry, from technology, and food safety, to agriculture and healthcare (Okwiri et al., 2014).

In this paper, we will specifically discuss about ISO 9001:2015 about Quality Management and ISO 14001:2015 about Environmental Management. Both of these standards are very important for industries as they will add brand value to their industries. Moreover, the certification itself acts as a proof for an industry to show that its products or services are of world-class quality. 
With all of these benefits, trust will be obtained from customers and clients thus they feel thus making more sales for the industry (Alhaddad, 2015).

This paper will discuss mining industries in Indonesia, other developing and developed countries. Mining industry involves a lot of engineering procedures such as drilling, activities related to explosion and exploration, that are often considered to have a negative impact on the environment and cause social disruption (Caron et al., 2016). Which is why a mining industry really needs ISO certification to make clients and consumers believe that what they do is in accordance to the international standards.

Therefore, it is important to know about the specification of ISO for mining industries. For the ISO 9001:2015, which talks about Quality Management, the standards are quite clear as they are relevant to all type of sectors. This standard is an upgrade from the previous ISO 9001:2008 which comes with several changes such as: Customer-focused; Leadership; Involvement of people; Process approach; Organizational context; continual improvement; Fact-based decision making; Risk-based thinking.

Certification in accordance with ISO 9001 helps organizations develop and improve performance and demonstrate high quality of service when they are bidding contracts. Certification follows the successful completion of an audit in accordance with ISO 9001 and enables organizations to (Tari et al, 2012) : Operate more efficiently; Meet statutory and regulatory requirements; Reach new markets; Identify and address risks.

ISO 14001:2015 sets out the environmental management system criteria and is certifiable. It establishes a framework that a company or an organization can follow in order to establish an effective environmental management system. Any organization can use it regardless of its activity or industry. Using ISO 14001:2015, companies and employees as well as external stakeholders can be assured that the impact on the environment is measured and improved (Riaz et al., 2019).

This standard is also an upgrade from ISO 14001:2004. The upgrades include (Fonseca, 2015): Increased emphasis on environmental management in the strategic planning processes of the organization; Focus on leadership; Addition of proactive environmental protection initiatives, such as sustainable use of resources and mitigation of climate change; improving environmental 
performance added; Lifecycle thinking when considering environmental aspects; Addition of a communications strategy.

It is also reported by ISO that the users of ISO 14001:2015 claim that it benefited the company in some way or the other. This benefits includes demonstrating compliance with existing and future legal and regulatory requirements; increasing the participation of employees in leadership and engagement; improving the company's reputation and stakeholder's confidence through strategic communication; achieving strategic business objectives by incorporating environmental issues into the management of business; providing a competitive and financial benefit by improving efficiencies and reducing costs; and promoting better suppliers' environmental performance by integrating them into the business systems of the organization.

The mining companies that will be discussed in this paper are KGHM from Poland, Coal India Limited from India, Bukit Asam and Latinusa from Indonesia. KGHM from Poland was chosen to represent a heavy metal mining industry in European countries with the title of the 49th largest mining industry in the world (Els, 2018). Coal India Limited was chosen to represent a coal mining industry in a developing country that holds the title of the world's 5th largest coal reserves (Akanksha, 2018). The two mining industries from Indonesia were chosen so that there will be a far comparison for both heavy metal mining industry and coal mining industry.

\section{METHODOLOGY}

This paper uses a qualitative research method by analyzing secondary data from the annual reports published by the companies or the websites of companies to find out the strategies that companies applied to achieve certification of ISO 9001:2015 and ISO 14001:2015 and also analyzing secondary data from journal and books that are related to environmental quality management system especially about the implementation of ISO 9001:2015 and ISO 14001:2015 in mining industries. A systematic approach to find related sources was done by do the initial observation by using google scholar to find related source by typing related keyword, such as current certification for environmental quality management system especially in ISO 9001:2015 and ISO 14001:2015, current mining industries that applied ISO 9001:2015 and ISO 14001:2015. Lastly, collect the required data needed about the strategies of the companies in

implementing ISO 9001:2015 and ISO 14001:2015 and compare the data about the strategies of the companies as well as analyze the result. 


\section{RESULT AND DISCUSSION}

\subsection{Mining Industry in Indonesia}

\subsubsection{PT Bukit Asam, Tbk}

PT Bukit Asam is a national company owned by BUMN (Badan Usaha Milik Negara) located in Tanjung Enim, South Sumatera, running in the coal mining sector since 1919, when Indonesia was still colonized by the Netherlands. It was first called Tambang Air Laya. After the colonization, in 1950, the name changed into PN TABA (Perusahaan Negara Tambang Arang Bukit Asam). Then in 1981, its name again changed into PT Bukit Asam which is shorten into PTBA. And it has never changed name since then. PT Bukit Asam had achieved gold PROPER 5 years in a row from 2013 until 2017. It has a total of 11 subsidiary companies. It has also achieved ISO 9001:2015, ISO 14001:2015 and OHSAS 18001:2007 on 2017. This shows that this company has really given their best effort to comply with the international standards (PT Bukit Asam, 2017).

\subsubsection{ISO 9001:2015 Implementation}

PT Bukit Asam has implemented risk-based thinking and also strived for continual improvement. This is shown from the annual report of PT Bukit Asam in 2017, which is also the year when they achieved their ISO certification. PT Bukit Asam has stated that they applied prudent principles or also known as risk-based thinking. This is proved by them establishing Risk Management Unit, Internal Audit Unit and Corporate Management System. Also, they have strived to improve continuously. This is proven by their rise in sales and revenue from 2016 to 2017 (see Table 1 and Table 2).

Table 1. PT Bukit Asam Coal Sales in Thousand Tons

\begin{tabular}{lcc}
\hline \multicolumn{3}{c}{ Coal Sales (Thousand Tons) } \\
\hline Market & $\mathbf{2 0 1 7}$ & $\mathbf{2 0 1 6}$ \\
\hline Domestic & $14,386,772$ & $12,251,107$ \\
\hline Export & $9,241,103$ & $8,502,059$ \\
\hline Total Sales & $23,627,875$ & $20,753,167$ \\
\hline
\end{tabular}

Source: PT Bukit Asam Annual Report 2017 
Table 2. PT Bukit Asam Coal Sales in Million Rupiah

\begin{tabular}{lcc}
\hline \multicolumn{3}{c}{ Coal Sales (Million Rupiah) } \\
\hline Description & $\mathbf{2 0 1 7}$ & $\mathbf{2 0 1 6}$ \\
\hline Revenue & $19,471,030$ & $14,058,869$ \\
\hline Cost of Revenue & {$[10,964,524]$} & {$[9,657,400]$} \\
\hline Total Comprehensive Income for the Year & $3,859,402$ & $1,875,631$ \\
\hline Profit Attributable to: & & \\
\hline Owner of the Parent & $4,476,444$ & $2,006,188$ \\
\hline Non-Controlling Interests & 70,788 & 18,217 \\
\hline
\end{tabular}

Source: PT Bukit Asam Annual Report 2017

\subsubsection{ISO 14001:2015 Implementation}

PT Bukit Asam has also implemented ISO 14001:2015 in their environmental management system. This is seen from their annual report where they stated that they have implemented their own environmental management system called SMBA (Sistem Manajemen Bukit Asam). Also, they have kept their commitment in following the national standards of emission, also striving in giving social incentives (See Table 3).

Table 3. PT Bukit Asam Environmental Management and Monitoring

\begin{tabular}{|c|c|}
\hline \multicolumn{2}{|r|}{ Conclusion of Environmental Management and Monitoring Result } \\
\hline Monitoring Area & 2017 \\
\hline Environmental Quality & All indicators of con \\
\hline Standards & Quality Standards. \\
\hline Maintaining & Biodiversity (Plankton, Benthos, and Nekton) in water \\
\hline Biodi & $\begin{array}{l}\text { Tanjung Enim Mining Unit in South Sumatera by the third party (PPLH Unsri), } \\
\text { indicated improvement in overall and able to support the life of aquatic biota. } \\
\text { The land sites of the former landfills have been rehabilitated and re-vegetated } \\
\text { and are able to support wildlife. In some locations, rare species of birds which } \\
\text { were protected by legislation such as Elang Alap Besra, Eagle Bats, King } \\
\text { Prawns, Meninting and Cekakak were found. In addition, there were also some } \\
\text { animal species of mammals, such as Lutung, Simpai and deer, and a protected } \\
\text { species of cobra were also found. }\end{array}$ \\
\hline Re-vegetation & $\begin{array}{l}\text { Overall, planting activities are already well underway, with a success growth } \\
\text { rate of re-vegetation plants above } 80 \% \text {, while the treatment activities need to be } \\
\text { improved. }\end{array}$ \\
\hline $\begin{array}{l}\text { Social } \\
\text { Culture }\end{array}$ & $\begin{array}{l}\text { Public perception of the Company's activities is very good, and they fully } \\
\text { support the mining activities. }\end{array}$ \\
\hline
\end{tabular}

Source: PT Bukit Asam Annual Report 2017 
PT Bukit Asam also strives for sustainability in energy and resources. They reuse and recycle waste as a substitute for coal and thus minimizing coal usage. Also, they started using their own electricity from the PLTU (Pembangkit Listrik Tenaga Uap) in order to decrease electricity usage from PLN (See Table 4).

Table 4. PT Bukit Asam Energy Consumption and Production

\begin{tabular}{|c|c|c|c|c|c|c|}
\hline \multicolumn{7}{|c|}{ PTBA Energy Consumption and Production } \\
\hline Source & Unit & 2017 & 2016 & 2015 & 2014 & 2013 \\
\hline $\begin{array}{l}\text { Solar } \\
\text { Fuel }\end{array}$ & $\begin{array}{c}\text { Joule } \\
\text { (thousand) }\end{array}$ & $4,232,918,138.49$ & $4,939,549,656.04$ & $3,401,186,455.74$ & $3,071,168,810.07$ & $2,766,329,767.85$ \\
\hline $\begin{array}{l}\text { Electrici } \\
\text { ty from } \\
\text { PTBA } \\
\text { Power } \\
\text { Plant }\end{array}$ & $\begin{array}{c}\text { Joule } \\
\text { (thousand) }\end{array}$ & $416,168,106.70$ & $482,781,328.43$ & $157,095,265.99$ & $136,910,660.56$ & $82,369,135.29$ \\
\hline $\begin{array}{l}\text { Electrici } \\
\text { ty form } \\
\text { PLN }\end{array}$ & $\begin{array}{c}\text { Joule } \\
\text { (thousand) }\end{array}$ & $1,499,530.51$ & $454,868.66$ & $37,095,155.80$ & $52,271,976.78$ & $73,321,841.34$ \\
\hline $\begin{array}{l}\text { Solar } \\
\text { Power }\end{array}$ & $\begin{array}{c}\text { Joule } \\
\text { (thousand) }\end{array}$ & $8,798.88$ & $8,798.88$ & $8,978.88$ & $8,978.88$ & $8,978.88$ \\
\hline Total & $\begin{array}{c}\text { Joule } \\
\text { (thousand) }\end{array}$ & $4,650,594,574.57$ & $5,422,794,652.00$ & $3,595,385,676.41$ & $3,260,360,246.29$ & $2,922,029,543.36$ \\
\hline
\end{tabular}

Source: PT Bukit Asam Annual Report 2017

\subsubsection{PT Plat Timah Nusantara Indonesia, Tbk}

PT Pelat Timah Nusantara Tbk (better recognized as Latinusa) is an Indonesian tinplate manufacturer. In accordance with ASTM, JIS, ISO and Euronom standards, the agency produces all sorts of tinplates. Latinusa always works to promote its recognition and competitiveness as a predominant dealer of high - quality tinplate packaging to maintain dominance and leadership in the countrywide tinplate market nowadays for massive industrial consumers. PT Pelat Timah Nusantara Tbk has been implemented the certification of ISO 9001:2015 and ISO 14001:2015 and it was implemented in 2016. Several strategies have been applied by PT Latinusa Tbk to achieve the certification of ISO 9001:2015 and ISO 14001:2015 which are describe below (Coal India Limited, 2017).

PT Pelat Timah Nusantara Tbk has been implemented the certification of ISO 9001:2015 and ISO 14001:2015 and it was implemented in 2016. Several strategies have been applied by PT Latinusa Tbk to achieve the certification of ISO 9001:2015 and ISO 14001:2015 which are described below. 


\subsubsection{ISO 9001:2015 Implementation}

\section{A. Corporate Strategy and Strategic Policy}

The focus of the service is to emphasizes the advantages of quality cost delivery, where Latinusa offers customers the best solution by offering the best quality products with tightly controlled costs and reliable delivery to ensure smooth routine production and business processes of customers. Latinusa also offers technical support that allows customers to plan their future business development (Coal India Limited, 2017).

\section{B. Human Resource Development Performance}

In line with the demands of business growth, Latinusa develops human resource skills and capabilities, with Manpower Planning 2020 as a reference for human resources aspects. The training system is designed to focus on internal processes by adapting the mentoring process to their respective staff for application by the supervisors (Coal India Limited, 2017).

\section{Production Facilities, Production Process, and Production Standard}

For a period of two years until the end of 2011, Latinusa completed the refurbishment project as a strategic initiative to modernize machine technology in order to improve production capacity in accordance with the operational standards of the leading international manufacturers of tinplate. Refurbishment is also aimed at expanding installed production capacity, so that Latinusa is able to support the overall growth of the national tinplate industry, both in terms of volume growth and improvement in the quality of specifications and more extensive uses.

For the production process, Latinusa switched to the insoluble anode technology for the Electrolytic Tinning Line ETL process, resulting in better tin coating quality compared to tinplate products processed using the previously used soluble technology.

Latinusa has equipped its operational activities at national and international levels with guidelines for certification and standardization of production. All these certifications ensure that all Latinusa operational processes and facilities comply with the required production standards (Coal India Limited, 2017).

\section{Continuous Improvement of Production Technology}

Some improvements in production processes have been designed to apply best environmental 
protection practices, including replacement of boilers, installation of wastewater cooling and implementation of pest control programs (Coal India Limited, 2017).

\subsubsection{ISO 14001:2015 Implementation}

\section{A. Environmental Pollution Risk Mitigation}

Latinusa's production facility is equipped with a comprehensive waste management system for liquid and solid waste as part of the control of pollution in the surrounding communities. The facility includes a waste water treatment plant for the disposal of liquid waste from the manufacturing process. The management of the disposal of solid waste from the production site is based on a cooperation/contractual agreement with a licensed waste management company to neutralize waste (Coal India Limited, 2017).

\section{B. Environmental Awareness}

These efforts include upgrading to superior production technology and using more efficient and environment friendly machinery, equipment and fuel alternatives. These measures for improvement include the implementation of energy conversion in boiler and tin particles, thereby facilitating the use of liquid natural gas as the primary source of fuel and reducing the use of electricity and pollutants in exhaust emissions. The company has also installed a water recycle project to ensure the sustainable use of wastewater during the production cycle (Coal India Limited, 2017).

\subsection{Mining Industry in Other Developing Country - India}

\subsubsection{Coal India Limited}

Coal India Limited (CIL) is a company with headquarters in Kolkata, West Bengal under the Ministry of Coal, India. CIL operates in 82 mining areas in eight Indian provincial states. The Indian Coal Management Institute (IICM) is an excellent training center operating under CIL and provides executives with multidisciplinary management developmental programs.

Coal India was accredited on 27 October 2016 with the certification of IS / ISO 9001:2015 (Quality Management System) and IS / ISO 50001:2011 (Energy Management System). The implementation of ISO 14001: 2015 (Environmental Management System) is now underway (KGHM Corporate, 2019). 


\subsubsection{ISO 9001:2015 Implementation}

\section{A. Consumer Satisfaction}

Special emphasis on quality management is placed on improved customer satisfaction. It was decided that 2017-18 would be declared as a 'Quality Year' in line with this objective. CIL has designed a portal to capture the entire life cycle of the sample to monitor the quality of coal internally. Complaints have been lodged online and remedied. The percentage of complaints resolved by consumers in 2016-17 is 99.42 percent (KGHM Corporate, 2019).

\subsubsection{ISO 14001:2015 Implementation}

\section{A. Pollution Control Measures and their Efficacy}

By practicing and following sustainable mining, Coal India has maintained the utmost importance in protecting the environment in order to ensure that mining operations have the least impact on the environment. Different measures and initiatives to control pollution are taken at the same time as mining operations in order to maintain acceptable/ permissible limits on the main physical and chemical attributes of the environment, namely air, water, hydrogeology, ground vibrations, noise, land and the nearby population (KGHM Corporate, 2019).

\subsection{Air Pollution Control Measures:}

Coal India Ltd has taken various initiatives based on the Environmental Management Plans (EMP) to control and reduce the generation of dust during drilling, blasting, loading and transport of coal, which have already been prepared before the start / improvement of coal mines production. Appropriate water spraying systems are being installed to arrest fugitive dust in roads, washrooms, CHPs, feeder breakers, crushers, coal transfer points and coal stock areas (KGHM Corporate, 2019).

\subsection{Mine Water Management:}

Water from underground and open cast mines is contaminated with suspended particles. During washing and cleaning, a small amount of water is contaminated. By treating this water, CIL also takes the initiative. After mine consumption, the treated water is supplied to the local villages. Final effluent quality is monitored in accordance with the relevant Indian standards (KGHM Corporate Website, 2019). 


\subsection{Noise Pollution Control Measure:}

In order to control noise pollution, the following measures are adopted, such as proper maintenance of equipment to minimize vibration, the green belt provided around the mine, as well as the residential area, controlled blasting and blasting in a single day, case of the surface miner, continuous mining of miners and high walls, which extract coal without blasting, ear muff or ear plugs supplied to workers in highly noisy areas (KGHM Corporate, 2019).

\subsection{Land Reclamation:}

The recovery of mined areas and external OB dumps is one of Coal India's major environmental mitigation activities. Concurrent reclamation and rehabilitation of mined out areas (subject to technical feasibility as per geo-mining conditions) are taken for gainful land use. Opencast mines are filled with overburden extracted during the coal extraction process and planting, which is referred to as biological recovery, is carried out after technical recovery (KGHM Corporate, 2019).

\subsection{Mining Industry in Other Developed Country - Poland}

\subsubsection{KGHM (Kombinat Górniczo-Hutniczy Miedzi) Polska Miedź S.A.}

KGHM extracts and processes valuable natural resources with the largest European deposits of copper ore in the south - western part of Poland in the heart of its catchment area. Due to its extensive experience, openness and constant skills improvement, the company has built a unique teamwork culture that ranks high on the international stage. KGHM's international position is systematically strengthened by the implementation of the development strategy. The company currently has a geographically diversified mining project portfolio. On three continents-Europe, North and South America-KGHM has located its facilities. KGHM has risen to the well-deserved position of a global leader in the mining industry with its control of over 22.7 million tons of copper ore resources worldwide. The company's portfolio also includes new metals such as molybdenum, palladium or nickel that help KGHM join the multi-resource international community (KGHM Polska Miedz, 2018).

\subsubsection{ISO 9001:2015 Implementation}

KGHM has implemented risk-based assessment in their policy based on their annual report in 2017 (Mkhaimer et al, 2017). Also, they have striven for continual improvement. They have a 
mindset of continuous improvement until there are 'zero harm'. (See Figure 1.)

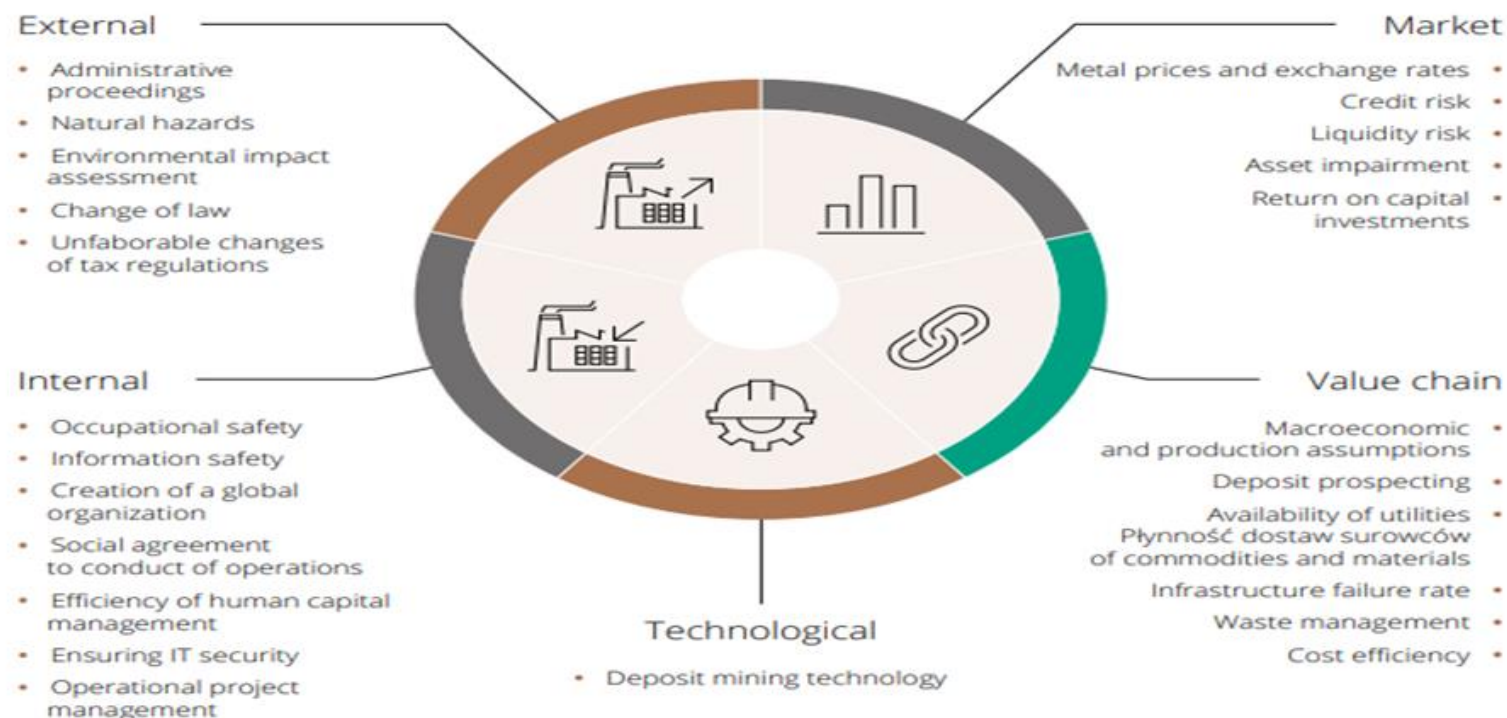

Figure 1. KGHM Risk Assessment Strategy

Source: KGHM Annual Report, 2017

\subsubsection{ISO 14001:2015 Implementation}

KGHM has implemented environmental policy based on their annual report in 2017 (Mkhaimer et al., 2017). This includes natural environment and climate change, waste management and availability of materials and utilities. (See Table 5)

Table 5. KGHM Environmental Policy

\begin{tabular}{|c|c|c|}
\hline Policy & Risk & Mitigation \\
\hline \multirow[t]{2}{*}{$\begin{array}{l}\text { Natural } \\
\text { Environment and } \\
\text { Climate Changes }\end{array}$} & $\begin{array}{l}\text { (KGHM Group) The extraction of } \\
\text { copper ore and its subsequent } \\
\text { processing at all levels of } \\
\text { production is inextricably linked to } \\
\text { certain components of the natural } \\
\text { environment. Risk associated with } \\
\text { prices and the } \mathrm{CO} 2 \text { emission limit } \\
\text { granted. }\end{array}$ & $\begin{array}{l}\text { The systematic modernization of } \\
\text { environmental protection facilities, both } \\
\text { those built in the past and new investments } \\
\text { in this field, enables compliance with } \\
\text { stringent environmental standards as a } \\
\text { result of the law. A CO2 Emissions } \\
\text { Management System and environmental } \\
\text { management standards of ISO } 14001 \text { were } \\
\text { implemented in the parent company. }\end{array}$ \\
\hline & $\begin{array}{l}\text { (Parent Company) Risk associated } \\
\text { with air quality assessment in the }\end{array}$ & $\begin{array}{l}\text { Performance of the duties resulting from } \\
\text { Air Protection Programs. }\end{array}$ \\
\hline
\end{tabular}




\begin{tabular}{|c|c|c|}
\hline Policy & Risk & Mitigation \\
\hline & $\begin{array}{l}\text { Dolnośląskie } \\
\text { Voivodship } \\
\text { (exceeding the average annual } \\
\text { target for arsenic in PM10 } \\
\text { particulate matter). }\end{array}$ & \\
\hline Waste Management & $\begin{array}{l}\text { (Parent Company) Risk of inability } \\
\text { to store flotation tailings }\end{array}$ & $\begin{array}{l}\text { Operation, construction and expansion of } \\
\text { the storage facility in accordance with the } \\
\text { operating manual. Cooperation with the } \\
\text { Team of International Experts } \\
\text { (Międzynarodowy Zespó Ekspertow - } \\
\text { ZEM) and the General Designer, } \\
\text { introduction of the Observation Method in } \\
\text { the period of expansion recommended by } \\
\text { ZEM based on the evaluation of } \\
\text { geotechnical parameters obtained through } \\
\text { evaluation of monitoring results that offer } \\
\text { the ability to request to keep the facility } \\
\text { being built/operated. Introduction of the } \\
\text { LCA model and circular economy. }\end{array}$ \\
\hline $\begin{array}{lr}\text { Availability } & \text { of } \\
\text { Materials } & \text { and } \\
\text { Utilities } & \end{array}$ & $\begin{array}{l}\text { (KGHM Group) Risk related to } \\
\text { unavailability of the necessary } \\
\text { utilities (electricity, natural gas, } \\
\text { water). }\end{array}$ & $\begin{array}{l}\text { Ensure that emergency supply systems are } \\
\text { in place for key utilities and conduct } \\
\text { ongoing evaluation of security of grid } \\
\text { power supply. Conduct several investment } \\
\text { projects to strengthen energy security. }\end{array}$ \\
\hline
\end{tabular}

Source: KGHM Annual Report 2017

\subsection{Comparison}

Table 6 shows the comparison of ISO 9001 and 14001 implementations between companies. It is further divided into mining industries in Indonesia, other developing country and developed country.

In comparison between coal and heavy metal industries we have researched about, it is clear that coal and heavy metal industry is very aware of the ISO Standards and strive to pursue them. It is clear that ISO standards became very important to them so that they can build a better relationship with customers. 
Table 6. Comparison of ISO 9001 and 14001 implementations between companies

\begin{tabular}{|c|c|}
\hline \multicolumn{2}{|r|}{ Mining Industries In Indonesia } \\
\hline \multicolumn{2}{|c|}{ Implementation of ISO 9001:2015 } \\
\hline \multirow[t]{2}{*}{ PT. Bukit Asam, Tbk } & $\begin{array}{l}\text { 1. Has implemented risk-based thinking and also strive for continual } \\
\text { improvement }\end{array}$ \\
\hline & 2. Applied prudent principles or also known as risk based thinking \\
\hline \multirow{8}{*}{$\begin{array}{l}\text { PT Plat Timah Nusantara } \\
\text { Indonesia, Tbk }\end{array}$} & 1. Using method of Quality cost delivery (QCDD) \\
\hline & $\begin{array}{l}\text { 2. Providing intensive and comprehensive services based on the concept of a } \\
\text { total solution provider }\end{array}$ \\
\hline & 3. Developed an in-house training center \\
\hline & 4. Modernize machine technology \\
\hline & $\begin{array}{l}\text { 5. Implements a comprehensive planning system for the procurement and } \\
\text { logistics of raw materials }\end{array}$ \\
\hline & $\begin{array}{l}\text { 6. Applies strict and consistent controls as a critical component in a series of } \\
\text { management activities }\end{array}$ \\
\hline & $\begin{array}{l}\text { 7. Implementation of a superior quality management system at each stage of } \\
\text { production }\end{array}$ \\
\hline & 8. Continuous Improvement of Production Technology \\
\hline \multicolumn{2}{|c|}{ Implementation of ISO 14001:2015 } \\
\hline \multirow[t]{3}{*}{ PT. Bukit Asam, Tbk } & $\begin{array}{l}\text { 1. Have implemented their own environmental management system called } \\
\text { SMBA (Sistem Manajemen Bukit Asam) }\end{array}$ \\
\hline & $\begin{array}{l}\text { 2. Have kept their commitment in following the national standards of } \\
\text { emission, also striving in giving social incentives }\end{array}$ \\
\hline & $\begin{array}{l}\text { 3. Re-use and recycle waste as a substitute for coal and thus minimizing coal } \\
\text { usage }\end{array}$ \\
\hline \multirow[t]{3}{*}{$\begin{array}{l}\text { PT Plat Timah Nusantara } \\
\text { Indonesia, Tbk }\end{array}$} & $\begin{array}{l}\text { 1. Constantly monitoring waste materials produced in manufacturing } \\
\text { facilities }\end{array}$ \\
\hline & $\begin{array}{l}\text { 2. Launched comprehensive and multidimensional improvements to its entire } \\
\text { production process }\end{array}$ \\
\hline & $\begin{array}{l}\text { 3. Upgrading to superior production technology and using more efficient and } \\
\text { environmentally friendly machinery }\end{array}$ \\
\hline \multicolumn{2}{|r|}{ Mining Industry In Other Developing Country } \\
\hline \multicolumn{2}{|c|}{ Implementation of ISO 9001:2015 } \\
\hline \multirow[t]{2}{*}{ Coal India Limited } & 1. Declared a 'Quality Year' in line with improvement customer satisfaction \\
\hline & $\begin{array}{l}\text { 2. Has designed a portal to capture the entire life cycle of the sample to } \\
\text { monitor the quality of coal internally }\end{array}$ \\
\hline \multicolumn{2}{|c|}{ Implementation of ISO 14001:2015 } \\
\hline \multirow[t]{4}{*}{ Coal India Limited } & 1. Conducting Air Pollution Control Measures \\
\hline & 2. Mine Water Management \\
\hline & 3. Noise Pollution Control Measures \\
\hline & 4. Land Reclamation \\
\hline \multicolumn{2}{|r|}{ MINING INDUSTRY IN DEVELOPED COUNTRY } \\
\hline \multicolumn{2}{|c|}{ Implementation of ISO 9001:2015 } \\
\hline \multirow[t]{2}{*}{ KGHM Polska Miedz } & 1. Continuous Improvement \\
\hline & 2. Risk-Based Assessment \\
\hline \multicolumn{2}{|c|}{ Implementation of ISO 14001:2015 } \\
\hline \multirow[t]{2}{*}{ KGHM Polska Miedz } & 1. Sustainability \\
\hline & 2. Risk-Based Assessment \\
\hline
\end{tabular}

\subsubsection{Analysis of ISO 9001:2015}

Coal industry in Indonesia such as PT Bukit Asam Tbk has implemented the ISO 9001:2015 
with several strategies of risk-based thinking and also strive for continual improvement. However, for coal industry in other developing country such as Coal India Limited, implementation of ISO 9001:2015 has been done by strategies such as declaration of 'Quality Year' in line with improving customer satisfaction. They have also designed a portal to capture the entire life cycle of the sample to monitor the quality of coal internally. Based on these strategies, Indonesia can learn from Coal India's industry to increase the quality management in coal industry since they are both developing countries.

Heavy metal industry in Indonesia such as PT Plat Timah Nusantara Indonesia Tbk has implemented the ISO 9001:2015 with several strategies such as using method of Quality cost delivery (QCDD), providing intensive and comprehensive services based on the concept of a total solution provider, developed an in-house training center, modernize machine technology, implements a comprehensive planning system for the procurement and logistics of raw materials, applies strict and consistent controls as a critical component in a series of management activities, implementation of a superior quality management system at each stage of production as well as continuous improvement of production technology. However, for heavy metal in developed country such as KGHM Polska Miedz has implemented ISO 9001:2015 with strategies such as continuous improvement and risk-based assessment which is same with heavy metal industry in Indonesia.

\subsubsection{Analysis of ISO 14001:2015}

Coal industry in Indonesia such as PT Bukit Asam Tbk has implemented the ISO 14001:2015 with several strategies such as they have implemented their own environmental management system called SMBA (Sistem Manajemen Bukit Asam), have kept their commitment in following the national standards of emission, also striving in giving social incentives, reuse and recycle waste as a substitute for coal and thus minimizing coal usage. However, for coal industry in other developing country such as Coal India Limited has implemented ISO 14001:2015 with strategies such as conducting air pollution control measures, mine water management, noise pollution control measure as well as land reclamation. Based on these strategies, Indonesia can learn from Coal India's industry to improve the environmental management. By adopting these strategies, monitoring of pollution in Indonesia will be better and it will result to a better environment. 
Heavy metal industry in Indonesia such as PT Plat Timah Nusantara Indonesia Tbk has implemented the ISO 14001:2015 with several strategies such as constantly monitoring waste materials produced in manufacturing facilities, launched comprehensive and multidimensional improvements to its entire production process, upgrading to superior production technology and using more efficient and environment friendly machinery. However, for heavy metal in developed country such as KGHM Polska Miedz has implemented ISO 14001:2015 with strategies such as sustainability and risk-based assessment. KGHM Polska Miedz applied three executory strategies (Development of International Assets, Production and Safety, Coherent Organization) and three support strategies (Corporate Social Responsibility, Innovation, and Financial Stability).

\subsection{Other ISO-Related Standards}

\subsubsection{ISO 50001 - Energy Management System}

ISO 50001 is based on the continuous improvement management system model, which is also used for other well - known standards such as ISO 9001 or ISO 14001. This facilitates the integration of energy management in organizations overall efforts to improve quality and environmental management.

ISO 50001:2018 provides a framework of requirements for organizations to: Develop a policy for more efficient use of energy; Fix targets and objectives to meet the policy; Use data to better understand and make decisions about energy use; Measure the results; Review how well the policy works, and; Continually improve energy management (Gorny, 2015).

\subsubsection{ISO 45001 - Occupational Health And Safety}

ISO 45001 applies to all organizations, irrespective of their size, industry or nature. It is designed to be integrated into existing management processes of an organization and follows the same high - level structure as other standards of ISO management systems, such as ISO 9001 (quality management) and ISO 14001 (environmental management).

Key potential benefits from use of the standard include: Reduction of workplace incidents; Reduced absenteeism and staff turnover, leading to increased productivity; Reduced cost of insurance premiums; Creation of a health and safety culture, whereby employees are encouraged to take an active role in their own $O H \& S$; Reinforced leadership commitment to proactively 
improve OH\&S performance; Ability to meet legal and regulatory requirements; Enhanced reputation; Improved staff morale (Gorny, 2015).

\section{CONCLUSION}

In conclusion, heavy metal and coal mining industries all over the world are aware of the environmental impacts they might cause. Thus making ISO 14001 very important to build trust with clients. Also, ISO 9001 gives them security for maintaining loyal customers as more trust is established with higher quality service and product. From the results, we can see that difference in strategies depends on each countries need. Therefore, all strategies which has been explained before will give lessons about the common and best practices of ISO implementation.

\section{ACKNOWLEDGEMENT}

We would like to give our gratitude towards our lecturer, Mr. Filson Maratur Sidjabat, for guiding us in making this paper. We also would like to say thanks to other lecturers in our study program who has support us in making the paper.

\section{REFERENCES}

Akanksha. (2019). Countries with the biggest coal reserves. Mining Technology, Mining News and Views Updated Daily, 04-June-2018. [Online]. https://www.miningtechnology.com/features/feature-the-worlds-biggest-coal-reserves-by-country/. [Accessed: 29 $9^{\text {th }}$ March 2019].

Alhaddad, A. (2015) . Perceived Quality, Brand Image and Brand Trust as Determinants of Brand Loyalty. Journal of Research in Business and Management, 3(4), pp. 1-8

Ali, M. (2015). Implementation Analysis of ISO 50001:2011 Energy Management System (EnMS) on a Small/Medium Enterprise. Technical Journal, University of Engineering and Technology (UET) Taxila, Pakistan, 20 (II)

Caron, J., Durand, S., and Asselin,H. (2016). Principles and criteria of sustainable development for the mineral exploration industry. Journal of Cleaner Production, 119, pp. 215-222

Coal India Limited. (2017). Producing Quality Coal. Transforming Lives. [online] https://alankit.com/pdf/Coal\%20India\%20Annual\%20Report\%202016-17\%20FINAL\%2012.8.2017.pdf .[Accessed : 23 ${ }^{\text {rd }}$ February 2019]. 
Els, F. (2018). Top 50 biggest mining companies. [Online]. http://www.mining.com/top-50biggest-mining-companies/. [Accessed: 29 ${ }^{\text {th }}$ March 2019].

Fonseca, L. (2015). ISO 14001:2015: An Improved Tool for Sustainability. Journal of Industrial Engineering and Management JIEM, 8(1): 37-50

Gorny, A. (2015). Occupational health and safety management in the international condition (consistent with objectives the ISO 45001 standard). Modern Management Review, XX (22): pp. 73-88.

KGHM. (2019). At a glance. KGHM Corporate Website. [Online]. https://kghm.com/en/aboutus/glance. [Accessed: 23 ${ }^{\text {rd }}$ February 2019]

KGHM Polska Miedz.(2018). Integrated Report for 2017. [online]. https://kghm.com/en/node/4991 .[Accessed : 23 ${ }^{\text {rd }}$ February 2019]

Mkhaimer, L., Arafeh, M and Sakhrieh, A. (2017). Effective implementation of ISO 50001 energy management system: Applying Lean Six Sigma approach. International Journal of Engineering Business Management, 9: 1-12.

Okwiri, O and Mbeche, I. (2014). ISO 9001 Certification Status and Organizational Quality Maturity. International Journal of Business and Social Science. 5 (10)

PT Bukit Asam, Tbk. (2017). Achieving EXCELLENCE for SUSTAINABLE GROWTH. [online]. http://www.ptba.co.id/id/csr/laporan-berkelanjutan .[Accessed : 22 ${ }^{\text {nd }}$ Febr uary2019].

PT Latinusa Tbk. (2017) . Strengthening Quality. [online]. http://www.latinusa.co.id/laporantahunan .[Accessed : 23 ${ }^{\text {rd }}$ February 2019].

Riaz, H., Saeed, A., Baloch, M S., Nasrullah and Khan, Z A. (2019). Valuation of Environmental Management Standard ISO 14001: Evidence from an Emerging Market. Journal of Risk and Financial Management, 12 (21).

Tari, J., Azorin, J and Heras, I. (2012). Benefits of the ISO 9001 and ISO 14001 standards: A literature review. Journal of Industrial Engineering and Management JIEM, 5(2): 297-322 